\title{
Urease Activity of the Cyanobacterium Anabaena cylindrica
}

\author{
By ALISON H. MACKERRAS AND GEOFFREY D. SMITH* \\ Department of Biochemistry, Faculty of Science, The Australian National University, \\ GPO Box 4, Canberra, ACT 2601, Australia
}

(Received 18 February 1986; revised 14 May 1986)

\begin{abstract}
The cyanobacterium Anabaena cylindrica was found to have nickel-dependent urease activity. Addition of nickel to a nickel-free culture led to recovery of urease activity. This was not prevented by chloramphenicol. Cell-free extracts of nickel-depleted cells did not regain activity upon addition of $\mathrm{Ni}^{2+}$. Enzyme synthesis was constitutive; similar urease activities occurred in urea-, $\mathrm{NO}_{3}^{-}$- or $\mathrm{NH}_{3}$-grown cultures or those grown under $\mathrm{N}_{2}$-fixing conditions. The urease activity had hyperbolic kinetics, with an apparent $K_{\mathrm{m}}$ with respect to urea of $1.3 \pm 0.6(\mathrm{SD}) \mathrm{mM}$. Enzyme activity was enhanced up to two fold by $\mathrm{MgSO}_{4}$ and $\mathrm{MnSO}_{4}$ at $\mathrm{pH} 7 \cdot 5$. At $10 \mathrm{~mm}$-urea, cells hydrolysed urea and excreted $\mathrm{NH}_{3}$ in excess of biosynthetic requirements.
\end{abstract}

\section{INTRODUCTION}

Cyanobacterial species have been reported to grow on urea as a nitrogen source (Fogg et al., 1973) but were first shown to possess urease (EC 3.5.1.5) activity by Berns et al. (1966). An alternative urea-degrading enzyme, urea amidolyase (EC 6.3.4.6), has been observed in yeasts and some unicellular green algae (Roon \& Levenberg, 1968, 1972); its presence explains the ability of these organisms to hydrolyse urea without a detectable urease.

The two enzymes differ markedly in their mechanisms and co-factor requirements. Urease requires no co-factors for urea hydrolysis while urea amidolyase is biotin-dependent and requires ATP, $\mathrm{Mg}^{2+}$ and $\mathrm{CO}_{2}$ or bicarbonate (Roon \& Levenberg, 1970). Urea amidolyase has two enzyme activities: urea carboxylase, which forms allophanate in an ATP-dependent carboxylation reaction, and allophanate hydrolase (Syrett \& Leftley, 1976). On the basis of these differences Syrett \& Leftley (1976) proposed three criteria for distinguishing urease and urea amidolyase in algal extracts: inhibition of urease by hydroxyurea, inhibition of urea amidolyase by avidin and the reversal of this inhibition by addition of excess biotin. In this paper we report the application of these criteria to urea hydrolysis by extracts of the cyanobacterium Anabaena cylindrica. Dixon et al. (1975) found that urease from jack beans is a nickel-containing metalloenzyme and subsequently other ureases have also been shown to be nickel-dependent (Schneider \& Kaltwasser, 1984). We have investigated the nickel-dependence of urea hydrolysis in $A$. cylindrica.

\section{METHODS}

Cyanobacterial growth. A. cylindrica ATCC 27899 was obtained from the American Type Culture Collection and grown as described by Daday et al. (1977) in the modified medium of Allen \& Arnon (1955). Cells were grown either under $\mathrm{N}_{2}$-fixing conditions in the absence of a combined nitrogen source or in the presence of urea ( $\left.2 \mathrm{mM}\right)$, $\left(\mathrm{NH}_{4}\right)_{2} \mathrm{HPO}_{4}(2 \mathrm{mM})$ or $\mathrm{NaNO}_{3}(4 \mathrm{mM})$. All components except phosphate and nickel were present at one-eighth the strength used by Allen \& Arnon (1955); phosphate was full strength ( $2 \mathrm{~mm}$ ) and nickel usually four times full strength $(0.68 \mu \mathrm{M}$; variations are specified for individual experiments). For some experiments cells were grown in nickel-depleted medium prepared as described by Daday et al. (1985). During growth cells were continuously sparged with $0.3 \% \mathrm{CO}_{2}$ in air at approximately $170 \mathrm{ml} \mathrm{min}-1$ under a light intensity of $150 \mu \mathrm{E} \mathrm{s}^{-1} \mathrm{~m}^{-2}$ (photosynthetically active radiation). Cells were harvested during exponential growth (less than 200 Klett units; Mallette, 1969). 
Assays. Cells were concentrated by centrifugation, resuspended in $50 \mathrm{~mm}-\mathrm{HEPES} / \mathrm{NaOH}, 1 \mathrm{~mm}-\mathrm{Na}$-EDTA, $\mathrm{pH} 7 \cdot 5$, and passed through a French pressure cell at $138 \mathrm{MPa}$. The resulting extract was centrifuged at $13000 \mathrm{~g}$ for $15 \mathrm{~min}\left(4^{\circ} \mathrm{C}\right)$. Supernatants were made $10 \mathrm{mM}$ in urea and $5 \mathrm{mM}$ in $\mathrm{MgSO}_{4}$ and incubated at $30^{\circ} \mathrm{C}$ for $30 \mathrm{~min}$. The reaction was stopped by addition of $1 \mathrm{M}-\mathrm{H}_{2} \mathrm{SO}_{4}$ (final concentration $10 \mathrm{mM}$ ). Released $\mathrm{NH}_{3}$ was measured with an Orion $\mathrm{NH}_{3}$ electrode (model no. 95-12, Orion Research) by adding $10 \mathrm{M}-\mathrm{NaOH}$ (final concentration $0 \cdot 1 \mathrm{M}$ ) to convert $\mathrm{NH}_{4}^{+}$into free $\mathrm{NH}_{3}$. Protein concentrations were measured by the method of Peterson (1977), standardized with bovine serum albumin. Acetohydroxamic acid, hydroxyurea and avidin were obtained from Sigma.

\section{RESULTS AND DISCUSSION}

Nature of the urea-degrading enyzme in A. cylindrica

Our results show that $A$. cylindrica, in common with other cyanobacteria tested (Syrett \& Leftley, 1976), has urease and not urea amidolyase activity (Table 1). Urea hydrolysis was not affected by avidin but was markedly inhibited by the urease inhibitors acetohydroxamic acid and hydroxyurea. Acetohydroxamic acid is a competitive inhibitor of urease (Kobashi et al., 1962). Hydroxyurea is an inhibitor, but is also a substrate for urease (Reithel, 1971; Blakeley et al., 1969), releasing one molecule of $\mathrm{NH}_{3}$ per molecule of hydroxyurea. The degree of inhibition thus changes with time of incubation. The activity eluted as a single band from Sephacryl S-300 (Pharmacia) equilibrated with $50 \mathrm{~mm}$-HEPES/NaOH, $1 \mathrm{~mm}-\mathrm{Na}_{2}$-EDTA, 1mM-dithiothreitol, pH 7.5 (result not shown), which is also consistent with the presence of a single urea-degrading enzyme.

\section{Nickel-dependence of urease activity}

The level of urease activity depended on the concentration of nickel in the medium (Fig. 1). Cells grown in the absence of nickel had negligible activity (typically less than $2 \%$ of that observed in cells grown with $\left.0.68 \mu \mathrm{M}-\mathrm{NiSO}_{4}\right)$. Addition of $\mathrm{NiSO}_{4}(0.68 \mu \mathrm{M})$ to such cultures resulted in the recovery of activity over approximately $24 \mathrm{~h}$ (Fig. 2). Chloramphenicol $(20 \mu \mathrm{g}$ $\mathrm{ml}^{-1}$ ) did not prevent the recovery in experiments done over $6 \mathrm{~h}$. After $24 \mathrm{~h}$ in the presence of chloramphenicol the cells had an apparently lower specific activity of urease than control cells but this may well have been due to nonspecific toxic effects over the longer time period. When extracts of cells grown in nickel-depleted medium were incubated with $1 \mu \mathrm{M}$ - or $5 \mathrm{mM}-\mathrm{NiSO}_{4}$ for $2 \mathrm{~h}$ before adding urea no increase in activity was observed. Thus like the jack bean enzyme $\boldsymbol{A}$. cylindrica urease was nickel-dependent (Dixon et al., 1975), but cellular components are required for incorporation of the metal to give an active enzyme.

\section{Properties of the urease activity}

The specific activity of urease varied from culture to culture, falling in the range 16 to $58 \mathrm{nmol}$ $\min ^{-1}$ (mg protein $)^{-1}$. The reason for the variation is not known but it may have reflected subtle variations in growth conditions. The enyzme in crude cell-free extracts had hyperbolic kinetics, indicating the reaction to be pseudo-first-order with respect to urea concentration. An apparent $K_{\mathrm{m}}$ value of $1.3 \pm 0.6(\mathrm{SD}) \mathrm{mm}$ was determined. Urease activity in crude extracts was affected by $\mathrm{Mg}^{2+}$ and $\mathrm{Mn}^{2+}$ in a fashion previously unreported for urease. Increasing concentrations of $\mathrm{MgSO}_{4}$ in the assay mixture resulted in increasing urease activity. Saturation occurred at approximately $5 \mathrm{mM}-\mathrm{MgSO}_{4}$. The effect was more pronounced at $\mathrm{pH} 7 \cdot 0$ than at $\mathrm{pH} 8 \cdot 0$. At $\mathrm{pH}$ $7 \cdot 5,5 \mathrm{~mm}-\mathrm{MgSO}_{4}$ typically produced a 1.6 to 2 -fold enhancement of activity. The effect was specific for $\mathrm{Mg}^{2+}$ and $\mathrm{Mn}^{2+}$ : other metal ions tested $\left(\mathrm{Fe}^{3+}, \mathrm{Ni}^{2+}, \mathrm{Co}^{2+}\right.$ and $\mathrm{Zn}^{2+}$, each at $10 \mathrm{mM}$ in the assay) were inhibitory (cf. Reithel, 1971).

\section{Regulation of urease synthesis}

The recovery of activity when $\mathrm{NiSO}_{4}$ was added to a nickel-depleted culture was not inhibited by chloramphenicol which suggested that urease protein was synthesized in the absence of $\mathrm{Ni}^{2+}$ and that its synthesis was constitutive. The lack of regulation of synthesis was confirmed by the presence of similar levels of urease activity during growth on urea $(2 \mathrm{mM}),\left(\mathrm{NH}_{4}\right)_{2} \mathrm{HPO}_{4}(2 \mathrm{mM})$, $\mathrm{NaNO}_{3}(4 \mathrm{mM})$ and under $\mathrm{N}_{2}$-fixing conditions (results not shown). Such phenomena have been 


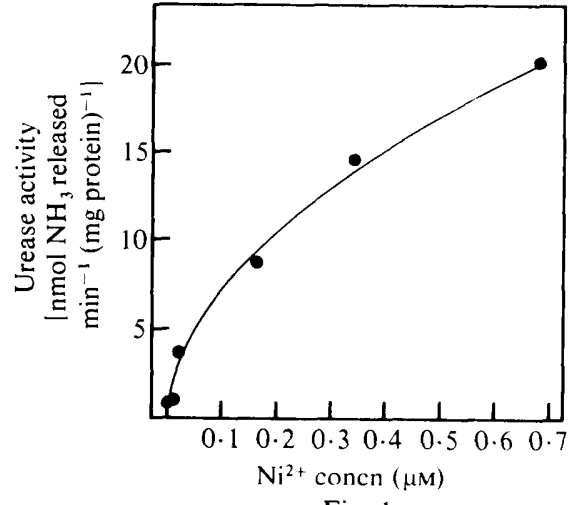

Fig. 1

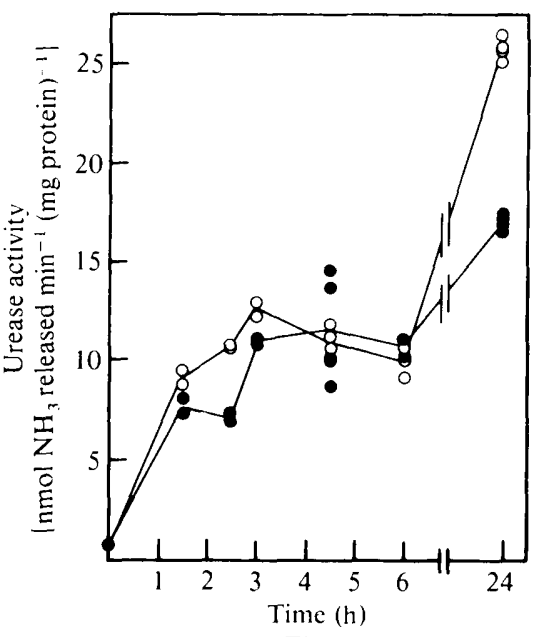

Fig. 2

Fig. 1. Dependence of urease activity in $A$. cylindrica on the $\mathrm{Ni}^{2+}$ concentration in the growth medium. Cells were grown in media supplemented with the indicated $\mathrm{Ni}^{2+}$ concentration and harvested at 170 Klett units. Extracts were prepared by French pressure cell disruption and urease activity was measured as described in Methods.

Fig. 2. Recovery of urease activity in cells grown in nickel-depleted growth medium. $\mathrm{NiSO}_{4}(0 \cdot 68 \mu \mathrm{M})$ was added at zero time and at appropriate times cell extracts were made and assayed $(O)$. A similar experiment was done but with chloramphenicol $\left(20 \mu \mathrm{g} \mathrm{ml}^{-1}\right)$ added immediately before the $\mathrm{NiSO}_{4}(\bigcirc)$.

Table 1. Differentiation between urease- and urea amidolyase-mediated urea hydrolysis in

$$
\text { A. cylindrica }
$$

A cell-free extract [specific activity $57 \mathrm{nmol} \mathrm{min}{ }^{-1}(\mathrm{mg} \text { protein })^{-1}$ ] was prepared and the initial rates of enzyme activity were measured in the presence of $10 \mathrm{mM}$-urea plus the indicated inhibitors. The rate of $\mathrm{NH}_{3}$ formed from hydroxyurea alone is also shown for a $60 \mathrm{~min}$ incubation.

$$
\text { Inhibitor }
$$

None

Acetohydroxamic acid

Hydroxyurea

Hydroxyurea without urea Avidin

$$
\text { Concentration }
$$

$$
10 \mathrm{~mm}
$$

$10 \mathrm{mM}$

$10 \mathrm{~mm}$

$50 \mu \mathrm{g} \mathrm{m}^{-1}$

Activity (\%)
100
5
27
4
100

observed with many cyanobacterial enzymes (Carr, 1973; Doolittle, 1979). Synthesis of a urease apoenzyme in the absence of nickel was observed in soybean seeds; no recovery of urease activity occurred on addition of $\mathrm{Ni}^{2+}$ to cell-free extracts (Winkler et al., 1983).

\section{Whole-cell urease activity}

When cells were grown in $10 \mathrm{~mm}$-urea significant amounts of $\mathrm{NH}_{3}$ appeared in the medium (up to $15 \mathrm{~mm}$ within $4 \mathrm{~d}$ ), resulting in cell death (observed as a rapid drop in Klett value, cell lysis and destruction of pigments) in some cases. $\mathrm{No} \mathrm{NH}_{3}$ was released in the absence of urea or when nickel-depleted cells were incubated in urea (results not shown). In cultures grown on $1 \mathrm{~mm}$-urea only transient increases in $\mathrm{NH}_{3}$ concentration (less than $0.2 \mathrm{~mm}$ ) were observed. Hence in conditions of high urea concentration the urease rate appeared to be significantly greater than the rate of $\mathrm{NH}_{3}$ incorporation by glutamine synthetase.

This possibility was tested further in shorter term experiments. With $10 \mathrm{~mm}$-urea a linear rate of $\mathrm{NH}_{3}$ release into the medium occurred for at least $60 \mathrm{~min}$; the rate was enhanced by only $30 \%$ when methionine sulphoximine ( $1 \mathrm{mM}$ ) was added to the cells $3 \mathrm{~h}$ before urea addition. Such a preincubation is known to inhibit further incorporation of $\mathrm{NH}_{3}$ via the glutamine synthetase 
reaction (Mackerras \& Smith, 1986). In the presence of methionine sulphoximine the rates of $\mathrm{NH}_{3}$ release from whole cells [3.2 $\mathrm{nmol} \mathrm{min}^{-1}$ (mg dry wt cells) $\left.{ }^{-1}\right]$ were close to (within $20 \%$ ) those measured in crude cell-free extracts. For such experiments it was important that a control with methionine sulphoximine but no urea also be included since significant amounts of $\mathrm{NH}_{3}$ are released from cells [typically $0.36 \mathrm{nmol} \mathrm{m^{-1 }}(\mathrm{mg} \text { dry wt cells })^{-1}$ ] as a result of other metabolic processes including $\mathrm{N}_{2}$-fixation, photorespiration and protein turnover. At lower concentrations of urea the effect of methionine sulfoximine was much more significant, presumably because the rate of incorporation of $\mathrm{NH}_{3}$ by glutamine synthetase is a greater proportion of the urease rate at the lower urea concentration, and possibly also because urea uptake becomes rate-limiting at lower concentrations.

Whole-cell measurements were used to assess the dependence of urease activity on urea concentration: the apparent $K_{\mathrm{m}}$ was not significantly different from that measured in cell-free extracts. A urea concentration of $10 \mathrm{~mm}$ was sufficient to saturate the enzyme in both cases.

In summary, we have shown that $A$. cylindrica has a constitutive nickel-dependent urease. However, ceils will grow efficiently in the total absence of nickel (Daday et al., 1985) and thus the precise role of urease in the nitrogen metabolism of this organism remains to be elucidated.

The authors acknowledge financial assistance from the Australian Research Grants Scheme (Grant No. D28315466 I) and the Australian National University Faculties Research Fund.

\section{REFERENCES}

Allen, M. B. \& ARnon, D. I. (1955). Studies on nitrogen-fixing blue-green algae. I. Growth and nitrogen fixation by Anabaena cylindrica Lemm. Plant Physiology 30, 366-372.

Berns, D. S., Holohan, P. \& ScotT, E. (1966) Urease activity in blue-green algae. Science 152, 1077-1078.

Blakeley, R. L., Hinds, J. A., Kunze, H. E., WebB, E. C. \& ZeRnER, B. (1969). Jack bean urease (EC 3.5.1.5). Demonstration of a carbamoyl-transfer reaction and inhibition by hydroxamic acids. Biochemistry 8, 1991-2000.

CarR, N. G. (1973). Metabolic control and autotrophic physiology. In The Biology of the Blue-green Algae, pp. 39-65. Edited by N. G. Carr \& B. A. Whitton. Oxford: Blackwell.

Daday, A., Platz, R. A. \& Smith, G. D. (1977). Anaerobic and aerobic hydrogen gas formation by the blue-green alga Anabaena cylindrica. Applied and Environmental Microbiology 34, 478-483.

Daday, A., Mackerras, A. H. \& Smith, G. D. (1985) The effect of nickel on hydrogen metabolism and nitrogen fixation in the cyanobacterium Anabaena cylindrica. Journal of General Microbiology 131, 231238.

Dixon, N. E., Gazzola, C., Blakeley, R. L. \& ZERNER, B. (1975). Jack bean urease (EC 3.5.1.5). A metalloenzyme. A simple biological role for nickel? Journal of the American Chemical Society 97 , 4131-4133.

Doolittle, W. F. (1979). The cyanobacterial genome, its expression and the control of that expression. Advances in Microbial Physiology 20, 1-102.

Fogg, G. E., Stewart, W. D. P., Fay, P. \& Walsby, A. E. (1973). In The Blue-green Algae, p. 207. London \& New York: Academic Press.

Kobashi, K., Hase, J. \& Ulhara, K. (1962). Specific inhibition of urease by hydroxamic acids. Biochimica et biophysica acta 65, 380-383.

MackerRas, A. H. \& Smith, G. D. (1986). Evidence for direct repression of nitrogenase by ammonia in the cyanobacterium Anabaena cylindrica. Biochemical and Biophysical Research Communications 134, 835-844.

Mallette, M. F. (1969). Evaluation of growth by physical and chemical means. Methods in Microbiology 1, 521- 566 .

Peterson, G. L. (1977). A simplification of the protein assay method of Lowry et al. which is more generally applicable. Analytical Biochemistry 83, 346-356.

ReITHEL, F. J. (1971). Ureases. In The Enzymes, 3rd edn, vol. 4, pp. 1-21. Edited by P. D. Boyer. London \& New York: Academic Press.

Roon, R. J. \& LevenberG, B. (1968). An adenosine triphosphate-dependent, avidin-sensitive enzymatic cleavage of urea in yeast and green algae. Journal of Biological Chemistry 243, 5213-5215.

RoON, R. J. \& LEVEnBERG, B. (1970). ATP : urea amidolyase (ADP) (Candida utilis). Methods in Enzymology 17, 317-324.

RoON, R. J. \& LEVENBERG, B. (1972). Urea amidolyase. I. Properties of the enzyme from Candida utilis. Journal of Biological Chemistry 247, 4107-4113.

SCHNEIDER, J. \& KaLTWASSER, H. (1984). Urease from Arthrobacter oxydans, a nickel-containing enzyme. Archives of Microbiology 139, 355-360.

Syrett, P. J. \& Leftey, J. W. (1976). Nitrate and urea assimilation by algae. In Perspectives in Experimental Biology, vol. 2, pp. 221-234. Edited by N. Sunderland. Oxford: Pergamon.

Winkler, R. G., Polacco, J. C., Eskew, D. L. \& WELCH, R. M. (1983). Nickel is not required for apourease synthesis in soybean seeds. Plant Physio$\log y$ 72, 262-263. 